Matthew, the church and anti-Semitism

F P Viljoen

(North-West University - Potchefstroom campus)

\begin{abstract}
\end{abstract}
\title{
Matthew, the church and anti-Semitism
}

The use of the noun ekklesia forms a distinctive feature in Matthew's Gospel. This term must have had a distinctive meaning for Matthew and his readers at the time he used it in his Gospel, though not as full blown as in the Pauline literature and later church history. At that stage the Matthean community considered itself outside the Jewish synagogues. This consideration can be noticed in the Matthean text, when reading the Matthean Jesus story as an "inclusive" story, including the story of the Matthean community. This story reveals a considerable portion of tension between the Matthean and Synagogue communities. An inattentive reading of this text has often unfairly led towards generalized Christian prejudice against all Jews. I argue that the conflict exposed in the text, must be read in context of the experiences of the Matthean community as to safeguard Christian from unjustified Anti-Semitism in general. Faith in or rejection of Jesus acts as dividing factor between the church and the synagogue, not ethnicity.

\section{INTRODUCTION}

Matthew has traditionally been characterized as the ecclesiastical gospel. Bornkamm's judgement is representative: "No other gospel is so shaped by the thought of the Church as Matthew's, so constructed for use by the Church; for this reason it has exercised, as no other, a normative influence on the later Church" (1963:38). Johnson (1986:172) begins his discussion of Matthew with the statement "Matthew is the gospel of the church". Though the mere appearance of a word in a text can not be used to characterize a specific text, it remains remarkable that unlike the other Gospels, Matthew contains the noun ekkl hsia $(16: 18 ; 18: 17)^{1}$. Read along with other references to the nature and functioning of this religious community, this emphasis of Matthew becomes evident. This article

1 Ekkl hsia must have been a familiar term to a Greek-speeking Jew, being the regular LXX translation for qahal, the congregation of the people of God (France 1998:211). 
does not attend to the church in Matthew in general, but to the church as alternative to the contemporary Jewish movements.

Along with this emphasis on the church, Matthew's text reveals an underlying conflict (Stanton 1993:26)). Matthew's gospel fits within the history of the complex Jewish-Christian relations of the first century. Carter (2000:1) labels Matthew a "counter narrative" against the Roman Imperial power and synagogical control. Especially the discourse of the woes (Mt 23) and the parables on salvation history (Mt 21:33-22:14) express such conflict (cf. Saldarini, 1994:46). Based on the struggle against the Jews as revealed in this narrative a Wirkungsgeschichte of this gospel has developed which sometimes sadly resulted in forms of anti-Semitism (Luz 2005:243).

When reflecting on this problem, one should seriously consider the context of the narrative and the intention of this Gospel.

\section{MATTHEW READ AS A TRANSPARENT STORY}

The Gospel can be read as a transparent story - a term which Luz (2005:17) has applied to Matthew. Although one should be careful to make a historical reconstruction of the gospel community based on the contents of the Gospel (as this requires a considerable amount of interpretation), one can regard the Matthean Jesus story as an "inclusive" story. From the text a reader can discover issues that were prevalent in the Gospel's community. Gospels obviously are more "open texts" and are less likely to have specific information of local situations as expected from letters (Bauckham 1998:48). Yet the different Gospel writers have addressed particular situations and issues. Thus the author of the Matthean gospel formed part of an early Christian congregation and he wrote his gospel with his congregation and its issues in mind (cf. Carter 2000:7; Klijn 1968:45).

In Matthew's Gospel a considerable number of emphases are apparent from which one can recognize some of the issues of those days, or to put it in other words; the Sitz im Leben der Kirche can indirectly be recognized in the Sitz im Leben Jesu as described in the Gospel material (White 1991:212). The Gospel therefore has a double meaning functioning on two levels (Luz 2005:27). It tells the story of Jesus, but in such a way that the story of the Matthean community can also be recognized in it (Saldarini 1991:39). The past story of Jesus and his disciples includes the story of the community's 
experience. Thus the disciples serve as a "transparency" for the later Matthean community and symbolize their attitudes and behaviour. On the first level Matthew tells the story of Jesus' fate in Israel. Jesus was rejected and executed in Israel while He pronounced judgement on Israel's leaders and its people and commissioned his disciples to preach to the Gentiles. On the second level he tells the story of the church's commitment to Jesus which resulted in their separation from the synagogue. Though many aspects of the Matthean community remain obscure, some stand out and make it possible to characterize Matthew's group (church) and its relation towards the non Christian Jewish community. It appears as if the church went through a dark period of being rejected by the synagogue and that they had to work through this traumatic experience. This grief is being expressed in the Gospel. The Gospel speaks of persecution (Mt 5:11-12; 10:23; 23:34) against missionaries on the part of Jews, of martyr deaths (Mt 10:21, 28; 22:5; 23:34, 37), of being handed over to Gentile courts (Mt 10:1718) and of divided families (Mt 10:34-37). Thus the second level of the story gives perspective on the church in a difficult period of reorientation because of this separation. The Gospel represents a (mainly-) Jewish Christian community in conflict with the Jewish mainstream and which has been expelled from the synagogues (Przybylski 1986:198).

Obviously, when reading this text as a transparent story one should be careful in making such social analyses. One must avoid turning the text into an allegory. Furthermore the narrative does not give a clear and unambiguous picture of the community, but provides data that have to be interpreted.

\section{NO GENERAL ANTI-SEMITISM BUT SPECIFIC ANTI- JUDAISM}

Many interpreters blame Matthew of being “anti-Jewish” (eg Luz 2005:243ff.). Matthew tells the story of increasing hostility, separation and victory of Jesus over his opponents. It also tells the story of the reckoning with Israel and the triumph of the coming judge of the world over his enemies. Jesus is being rejected by the Jewish leaders and by the chosen people (Mt 23:34-39; 27:24-25). The result is that Israel ceases to be the people of promise (Mt 21:43) and that the church succeeds them. The people who do not follow Jesus will not escape God's judgement (cf. Mt 24:1-2). 
Matthew describes the synagogues as places of hypocrisy and the Jewish religious leaders as hypocrites (Carter 2000:5). Many readings of the Matthean texts in the post-history of Matthew's Gospel highlighting these conflicts have resulted in forms of antiSemitism. Some scholars keep Matthew responsible for this later development.

One should keep in mind that the term anti-Semitism refers to a religiously motivated rejection of Semitics in general. Therefore it is unfitting to label Matthew as an anti-Semitist as such. Matthew himself was a Jew ${ }^{2}$ and while the church consisted of both Jewish and Gentile Christians, the core of the Matthean community was formed by Jews. The Jewish Christian community did not come in conflict with all Jews, but with Jews who formed part and were controlled by specific Judaistic movements. The Jewish Christians have been expelled from the synagogues of their community as Matthew refers to "their" or "your" synagogues (Mt 4:23; 9:35; 10:17; etc.). It remains remarkable that New Testament authors who judged the Jews most harshly, as Matthew and John did, were Jewish Christians themselves. Radford Reuther (1974:30) therefore rightly argues that one should distinguish between ancient anti-Semitism in general and specific anti-Judaism of Christians who experienced tensions with specific Jewish developments. Matthew himself has anticipated this term "anti-Judaism" in his critical use of Jouda i o i" in Matthew 28:15. Radford Reuther (1974:30) describes the later as

2 The hostility towards "Judaism" and a favourable attitude towards Gentile mission have led some scholars to suggest that the author of the gospel could not have been a Jew, and that he was not writing for Jews, eg. Clark (1947:165-172), Nepper-Christensen (1958:202-208) and Strecker (1971:1535). Other scholars, however, have no difficulty in suggesting that the author was a Jew (Hare 1967:147-148; Stanton 1977:67-83). Luz (1990:79) views the anti-Jewishness rather as argument for a Jewish-Christian setting: "It is to be expected especially of Jewish Christians that they would carry on with great intensity the debate with the synagogue, which remained far from Jesus, and would arrive at a severe judgment on Israel”. Luz substantiates his argument by indicating the strong influence of Matthew's Gospel on several JewishChristian writings (Luz 1990:81). Taking the paradox of the "Jewish" and "anti-Jewish" characteristics of Matthew's Gospel into account, the more plausible explanation therefore remains that the author was writing in the painful situation of a Jew who followed Jesus and therefore experienced increasing tension with official Judaism (cf. White 1991:227). 
"family conflict" associated with "rival claims to exclusive truth within the same religious symbol system". Hummel (1966:55) regards this tension as a rival amongst feindliche Brüder. It is very often the case that the closer the relationship between groups, the more intense the conflict between them (Coser 1998:67). In its self definition a group competes with other related groups. The tension of the Matthean community with other Jewish groups was born from proximity rather than distance (White 1991:241).

However, this "family conflict" needs specification. The conflict of Matthew's community is generally being described as a conflict with Judaism as the mother religion. This makes the Matthean community the rebellious daughter of her mother Jewish religion. Overman (1990:33) however has convincingly indicated that in the time of Jesus a transition has taken place from a "normative" Judaism into largely "sectarian" Judaisms. At the time of Jesus rival Jewish sects isolated themselves from each other defining themselves as the remnant of the core of Israel. Amongst these sects were the Essenes, the Pharisees, the Sadducees, the Zealots and various quietist-pietistic apocalyptic groups. Within this intra-Jewish conflict Jewish sects competed for self definition. Thus the "Jesus-movement" was caught up in this rival amongst Jewish religious groups. The Jewish Christians defined themselves distinct from the other current Judaistic movements (Saldarini 1991:49). Luz (2000:255) aptly argues that the conflict between Matthew and the current Judaism should not be defined merely as mother-daughter conflict, but rather as a rival between siblings. Matthew's polemics are not aimed against Jewish people as a whole, but against a certain interpretation of Judaism (from another sibling) and its opposing leaders and occasionally against the people who followed these leaders rejecting Matthew's community and its understanding of God's will (Saldarini 1994:44).

Anti-Judaistic arguments played an important role in the selfdefinition of the Christian community in the crises of separation and transition. There were specific socio historical reasons for such presentations of the synagogues and their leaders. One should, however, not generalize the Gospel's verdicts (Carter 2000:6). All synagogues are not places of violence and hypocrisy. Nevertheless, what was applicable to that specific situation sadly became a common feature of Christianity through the ages - independent from this specific historical situation. Some readers of the Matthean 
narrative made the Matthean self-definition, specific as it was directed to a particular situation, a permanent feature of Christianity, quite independent of specific historical situations. As a result Jewish people often became the victims of general Christian prejudice. In the holocaust some of the terrible consequences of such an inattentive reading or the text come to the fore. Matthew should not be held responsible for this later development. Matthew 27:25 indicates that Matthew probably saw a disaster descending on Israel, namely the destruction of Jerusalem and the temple. Matthew did not want to curse Israel for all centuries. He interpreted the destruction of Jerusalem as God's punishment for the rejection of Jesus.

\section{SEPARATION AND ECCLESIASTICAL ORGANISA- TION}

Specific anti-Judaistic arguments formed part of the Christian selfdefinition of the "church" (ekkl hsir), a noun which Matthew uses twice in his Gospel. Yet this does not mean that Matthew had a highly developed ecclesiastical organisation as found in the Pastoral Epistles and the corpus Paulinum. Some commentators attributed to Matthew's use of ekklhsi the technical Christian meaning. However, its use in Matthew should be determined by its immediate literary and social context. From this context it is clear that Matthew is not concerned with formal structures which the word "ecclesiastical" generally invokes (Saldarini 1994:91). Bornkamm (1963:38) remarks "only the most meagre beginnings of a real ecclesiology centred in the Church as an independent, empirically circumscribed entity, are to be found in Matthew's Gospel”. Nevertheless, in both passages where the word ekklhsi is used, the authoritative function of the church is specifically mentioned. This indicates that Matthew has a distinctive understanding of the nature of the church (France 1989:244).

\subsection{Conflict and separation in the narrative thread}

The narrative thread of Matthew's Gospel tells of Jesus' increasing conflict with Israel (Luz 2005:244). The story consists of a prologue and five main sections.

The prologue (Mt 1:1-4:22) anticipates this separation with Jesus' journey form the royal city of Bethlehem to the Galilee of the Gentiles (Mt 4:14-16). This is followed by the main narrative beginning in Matthew 4:23. In the first section (Mt 4:23-11:30) the proclamation and healing by Israel's Messiah amongst his people is 
told. This leads to the double ending that describes the split between the unrepentant Israel and the "infants" to whom the Son reveals the Father (Mt 11:20-24 and 11:25-30). The second section (Mt 12:116:20) narrates a series of episodes how Jesus and his disciples withdrew from the increasing hostility from Israel's leaders (Mt $12: 15 ; 14: 13 ; 15: 21 ; 16: 4)$. Within this increasing hostility from Israel, the community of disciples emerges. The section ends with Peter's declaration and of the building of the church (Mt 16:13-20). The third section describes a peaceful interlude in the life of Jesus before the onset of the church. This outlines the life of the community found among the disciples (Mt 16:21-20:34). Then follows a section on the final reckoning with Israel (Mt 21-25). After an introit, Jesus confronts Israel and its leaders with three salvation history parables (Mt 21:28-22:14), gets involved in disputes with Jewish groups (Mt 22:15-46), and ends with the great woes discourse (Mt 23). Jesus then leaves Israel's temple (Mt 24:1-2) and prepares the community for the day of judgement (Mt 24:3-25:46). The Passion and Easter narratives bring the Gospel to a conclusion (Mt 26-28). “The story of Jesus' resurrection (28:1-10) is a story of death for Israel and its leaders" (Luz 2005:245). They fail to recognize the truth of Jesus' resurrection (Mt 28:11-15). This negative ending parallels a positive development. The Lord commands his disciples to make disciples of all the nations and promises to be with them to the end of the world (Mt 28:16-20). This double ending of Matthew's story leads to a hopeless situation for Jews who do not recognize Jesus and a new mission for the disciples.

On the second level of the story this separation reflects the contemporary situation of Matthew's community. They have been separated from Israel and were in process of reorientating themselves outside the synagogue ${ }^{3}$. The mission to Israel is much resisted and the future of the mission also includes Gentiles. The people of Israel have been misled by the Pharisees. The author gives an outlook on the present. The rumour that the body of Jesus was stolen is still told "to this day" among the "Jews" (Mt 28:15). The second outlook on the present is found in the final pericope (Mt

3 The disciples with whom the intended audience of Matthew's Gospel identify find themselves outside the synagogues (Mt 4:23; 9:35; 10:17; etc.). 
28:16-20): The risen Lord remains with his community who are being sent to the Gentiles.

\subsection{The church regarded as the true remnant of Israel}

Matthew's definition of the church relies on his understanding of the relation between the church and Israel. Tagawa (1969/70:159) remarks that Matthew has a very strong consciousness of being part of a community, but fails to explain the relation between Israel and the church: "He is clearly aware of the fact that the people Israel and the Christian Church are not directly equal, but on the other hand, he confuses them". However, such a reading of Matthew lacks to recognize the Israel-Church typology in the Gospel.

Among the many quotations from the Old Testament (sometimes being stigmatised as artificial) which Matthew claims to be fulfilled, is the formula quotation from Hosea 11:1 in Matthew 2:15: "Out of Egypt I have called my son". This quotation is a reflection of the exodus of Israel from Egypt. Matthew regards the new people of God as parallel to Israel, and their deliverance from sin as the fulfilment of the exodus deliverance (France 1998:207). Matthew goes further by proposing that Israel, as referred to as God's son, finds its fulfilment not in a community in the first place, but in an individual, the Son of God. Israel's initial call out of Egypt points forward to Jesus' personal return from Egypt. Matthew's Jesus becomes a corporate figure; "The Messiah is not only founder and leader of the Israel-to-be, the new people of God; he is its 'inclusive representative'. In a real sense he is the true Israel, carrying through in his own experience the process through which it comes into being” (Dodd 1970:106). Those who follow Jesus thus formed a new community of the restored people of God. They are seen as the true continuation of Israel (Versteeg 1980:27).

Matthew's Jesus refers to this new community as the ekkl hs i a (Mt 16:18 and 18:17). Being a general LXX translation for qahal, the congregation of the people of God (eg. Dt 31:30), Jesus uses the term to describe the group of restored Israelites which He was gathering around Himself. However, s una g wg h vhas also commonly been used as translation of qahal (Keener 1999:428). In the usage of this emotive concept from the Old Testament, and translating it distinctively as ekklhsia, Matthew obviously intends to indicate that the Church took over the role of the Old Testament congregation of the people of God and distinguishes them from the synagogue and 
its leaders. The ekklhsid is an identifiable formal group, but Matthew does not use the term in the full blown meaning as by Paul and in later church history. Matthew's Jesus depicts his community as the true, faithful remnant of Israel in continuity of the Old Testament covenant community. Matthew's audience probably was small in number, forming a minority community within the larger dominant society (Carter 2000:27). In the beatitudes Jesus describes his disciples as the "poor" and the "meek" (Mt 5:3-5). These are well known Old Testament descriptions of the true "remnant" of the nation of Israel. The statement that the meek "shall inherit the earth"

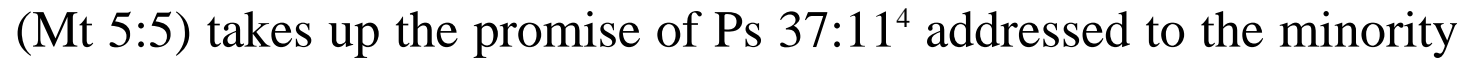
within Israel (Betz 1995:125). The combination of "small" but "special" builds on a Hebrew Bible tradition that is reinterpreted for the Matthean community. The Hebrew Scriptures attested God's election of Israel precisely because they were "the fewest of all peoples" (cf. Dt 7:7-8). This idea of the church as the true fulfilment of Israel played a significant role in Matthew's understanding of the community of those who belong to Jesus and the way the community would have listened to this Gospel.

The description of the church as the true remnant of Israel obviously has its negative side with regard to the rest of Israel. The failures of that part of Israel and their judgement are starkly pronounced. When Jesus asked who the people were saying He was, Jeremiah is included in Matthew's account (Mt 16:14). This was not a random choice. In popular thought Jeremiah, above all, have been characterized as the prophet of doom (France 1998:214). The one specific charge against Jesus by the Sanhedrin was his alleged threatening of the temple (Mt 26:61). According to evidence, contemporary messianic expectations included the purification, restoration and even replacement of the temple and its worship (Telford 1980:260) ${ }^{5}$. For Matthew the destruction of the temple in 70 $\mathrm{AD}$ therefore probably came as no surprise but as the appropriate outworking of that "something greater" that took its place.

Old Testament psalmists and prophets frequently accused the ungodly attitude of their contemporaries. Matthew picked up these

4 "But the meek will inherit the land and enjoy great peace".

5 A most prominent expression of such an ideology in the Old Testament is the vision of the new temple in Ez 40-47. 
denunciations and applied them to the enemies of Jesus. The shortcomings of Israel found their fuller expression in the actions of "this generation". Matthew listed a series of such denunciations (eg. Mt 11:16; 12:39-45: 16:4; 17:17). Matthew's gospel indicates that "this generation" is culpable and ripe for judgement. It is apparent that Matthew's attitude derived from a "holy hatred" vividly expressed by Old Testament psalmists against the enemies of God, those who obstruct the fulfilment of his purpose.

The strongest polemic in Matthew occurs in chapter 23, which concludes with the culpability of "this generation". But the seven "woes" are specifically directed at the scribes and the Pharisees, while the audience was Jesus' disciples as well as the "crowds" (0i] oploi). Matthew presents the crowds, specifically in the earlier stages of Jesus' ministry, as favourable. They were still open to Jesus' message, but also vulnerable to misleading by the Jewish leaders (Saldarini 1994:43; Van Tilborg 1972:160). The ordinary Jews (crowds) were not so much opposing Jesus, but were the uncommitted majority for whose loyalty Jesus had to compete with against the Pharisees and Sadducees (cf. Mt 16:6-12). Sadly the positive presentation of the crowds in the earlier ministry of Jesus changed in the passion narrative as they had sided with the wrong camp. The sympathetic detachment of the Jerusalem crowds changed into active hostility.

\subsection{Separation from Synagogues}

Considering the second level of Matthew's plot it becomes evident that some sort of Pharisaic grouping competed for authority and influence of popular thought in Matthew's community. Matthew expresses that the Pharisees were not supposed to be the leaders and spokespersons of their religious community. Matthew critiques the Jewish leadership. He intensifies the conflict of the narratives he took over from Mark (Carter 2000:32; Keener 1999:46; Repschinski 2000:63ff.). He intensifies Mark's references to the religious leaders' role in opposing and killing Jesus. Unique to Matthew is his depiction of the scribes and Pharisees as "blind guides" and "blind fools" (Mt 23:16, 17, 19, 24, 26; 15:14). Since "seeing" is associated with comprehending disciples (Mt 13:10-17) and "wisdom" with Jesus (Mt 11:25-30), the Jewish leaders are condemned for not allying with Jesus. Matthew clearly identifies the Jewish leaders as Jesus' opponents, while the crowds often serve as the audience of 
these conflicts. Matthew represents Jesus as the undisputed conqueror in all these contests. These controversies demonstrate a derogation of the Jewish leadership, which suggests that Jesus and his opponents were competing for the leadership of the crowds. This heightened conflict with the Pharisees reveals the tension of the community in which Matthew is writing. This conflict probably is connected with the destruction of Jerusalem, the temple and the priesthood in $70 \mathrm{CE}$. The following decades were times of much anguish and debate as various groups struggled with what had happened and what the future would look like. Reformulation of Judaism and the emergence of Pharisaic leadership surfaced to provide new theological understanding and patterns of worship (Carter 2000:33). "Matthew intends the audience of the controversy stories to reflect a group that turns from the fraudulent leadership of the opponents of Jesus towards an acknowledgement of the Matthean community as the rightful leaders of Israel” (Repschinski 2000:329). The Jewish leaders are depicted as negative "types" in contrast to the leaders of the church. Biblical tradition had often spoken of "building up" the community of God. Jesus replaces the "builders" who rejected Him (Ps 118:22; Mt 21:42) with his loyal disciples.

The Matthean community started to form their own structures separately from the synagogues. Synagogues functioned as community centres for an ethnic group, being a place not only for worship, but also for political organization, communal selfregulation and social and educational interaction (Carter 2000:31). A breach has developed between the Matthean community and nonChristian Judaism of the synagogue (Mohrlang 1984:131). Being in conflict with the synagogue was not simply a religious matter of not being welcome in a building. It meant estrangement form one's people and community. It had political, social, economic and familial implications. The expression "the parting of the ways" as introduced by Dunn $(1980 ; 1991)$ and popularized by Stanton (1983; 1992:99-116) marks this separation ${ }^{6}$. Matthew uses the phrase "their

6 Stanton provides a careful analysis of whether the debate with Judaism was being conducted intra muros or extra muros. Whether a complete separation had been achieved does not seem likely (White 1991:215). It is often assumed that the transition between these two phases should be linked with the introduction of the Birkath ha-Minim in the Shemoneh 'Esreh, their daily prayer ("Let Nazarenes (Christians) and minim (heretics) perish in a moment, 
synagogues” five times (Mt 4:23; 9:35; 10:17; 12:9; 13:54) and "your synagogue" once (Mt 23:34) to underline the distance between Jesus and the synagogue community. Several of these passages also emphasize hostility between the synagogue and Jesus' disciples. In Matthew 10:17 Jesus warns his disciples that they will be flogged in "their" synagogues. In Matthew 13:54-58 "their" synagogues reject Jesus. In Matthew 6:2 and 5 and 23:6 the behaviour of the "hypocrites in the synagogues" is condemned and contrasted with that of "you" in the Christian groups.

The Matthean community left the synagogues and its members had to choose between their Jewish brothers and sisters, fathers and mothers, fields and houses, and the Jesus community (Mt 19:29). They chose faith and loyalty to the new community which resulted in dissonance with the old (White 1991:216). Bornkamm (1963:40) describes how the Matthean church was distinguished from Judaism: "no longer Temple and sacrifices, ritual laws and circumcision (the later is not once mentioned in Matthew's gospel), nor the rabbinical teaching of the synagogue, but neither a new cultic or hierarchical order; rather discipleship" form the identity markers of this new community. As a separated minority the Jewish Christians thus strengthened their new cohesion.

\subsection{Inclusion of the nations}

Tension between the synagogue and the church intensified as nonJews were incorporated into the Christian community. Matthew argues that the purpose of God in fulfilling the Old Testament promises was to be discerned to a wider front than only the ethnic Israel (Saldarini 1991:51). Thus the Jewish-Christian community stood at a turning point. The destruction of Jerusalem in the Jewish War has been experienced by the Jewish-Christian community as the judgment of God on Israel. Various writers interpreted Jerusalem's destruction as God's punishment (eg. Josephus, 4 Esra, 2 Baruch). Matthew agrees, but particularizes the sin as the elite's rejection of Jesus and their misleading of the people (Mt 21:12-13, 18-19, 41-43;

let them be blotted out of the book of the living, and let them not be written with the righteous" (as quoted by France 1998:85) around AD 85 (eg. Burridge 1994:91). It is relatively sure that Matthew was composed in the general period in which this Jewish benediction was first formulated which could have had a significant impact upon Jewish-Christian relations, though some more recent scholars tend to question this benediction's influence (Horbury 1982:19-61). 
22:7; 27:25) (Carter 2000:34). These circumstances provoked the community to carry the great commandment of Jesus to proclaim his teaching to the Gentiles. This decision must have been controversial in the Jewish community. In a Hellenistic culture within the Roman Empire the Jews struggled to maintain their unique identity. This resulted in a strong tendency towards exclusiveness, which would specifically be evident in the synagogue. In contrast to this exclusivity, the Matthean community advocated the inclusion of gentiles who converted to Christianity. This created much tension with the synagogue (Repschinski 2000:27) which led towards a break with the contemporary Judaism of the synagogue. Luz (1990:84) proposes that Matthew elected himself as advocate to defend his community's decision for the Gentile mission. Hare writes: "the invitation which Israel has refused so rudely is now to be offered exclusively to the Gentiles" which "assumes the abandonment of the mission to Israel" (Hare 1967:147-148). However, the Christian community did not abandon the mission to Israel overall (Saldarini 1994:43). They still tried to convince Jews to understand their relation to God according to the teachings of Jesus.

Matthew's attitude towards Israel and the nations is ambiguous. The Gospel contains seemingly contradictory evidence with regard to Jesus' attitude to Jews and Gentiles respectively. On the one hand one finds a very particularistic tendency in Jesus' restriction in the mission of the Twelve (Mt 10:5-67, 23 ${ }^{8}$ ) and Jesus' seemingly harsh declaration towards the Canaanite woman (Mt $\left.15: 24^{9}\right)^{10}$. On the other hand the so-called great commission (Mt 28:18-20 ${ }^{11}$ ) calls for a mission to all nations ${ }^{12}$. How this relation has to be understood, has long been debated.

\footnotetext{
$7 \quad$ "Jesus sent out the twelve with the following instructions: "Do not go among the Gentiles or enter any town of the Samaritans. Go rather to the lost sheep of Israel.”

8 "I tell you the truth, you will not finish going through the cities of Israel before the Son of Man comes."

9 "He answered, 'I was sent only to the lost sheep of Israel.",

10 Mt 5:17-20 and 23:2-3 similarly exhibit strong Jewish traditions.

11 "Therefore go and make disciples of all nations ..."

12 Stark anti-Jewish texts appear in Mt 8:11-12; 23:29-36; 27:24-25.
} 
An easy solution would be to regard Matthew as a mere anthologist, as the source critics proposed already a century ago (eg. Streeter 1924:225). Matthew 10:5-6 and 15:24 are simply allotted to the M-source that has a Judaistic tendency. Such an approached has been criticized by redaction critics. The daughter of the Canaanite woman was healed and her mother was commended for her faith which does not fit a Judaistic tendency (Stanton 1992:47; Meier 1976:27). Yet some source-critical arguments are found among redaction critical scholars as well. Abel (1971:138) proposes that two redactors with different theological agendas worked together to compile the gospel. Brown (1961:27) suggests that there must have been two M-editors, otherwise Matthew would become "a monster; at once the most pro-Jewish and pro-Gentile of the Evangelists". According to Luz (1990:84) change in attitude towards the nations reveals a fracture between the "commission of the risen Lord" (Mt 28:19f.) and of the "earthly Jesus" (Mt 10:5f.) ${ }^{13}$. The combination of seemingly contradictory elements should rather be explained as a result of conflict which the community experienced. Some gentiles played a special role in Matthew's narrative. They are praised for their recognition of Jesus (eg. the magi and the centurion at the cross) and for the faith and confidence in Jesus' power to heal (the centurion and Canaanite woman). They are contrasted with unfaithful Jews who rejected Jesus (eg. the magi vs. Herod, the centurion vs. the Jewish leaders who condemned Jesus).

Another possibility is to read Matthew heilsgeschichtlich. This would imply that Matthew 10 and 15 should be read as pasthistorical reports of Jesus' mission according to which the hardness of Israel and her rejection of Jesus are demonstrated. The mission towards Israel should be redirected towards the gentiles (Mt 28). The particular mission to Israel then forms part of Matthew's general portrayal of a rejected and guilty Israel (Martin 1975:44). Such an interpretation would path the way for the existence of a church that would include gentiles. Yet, it is possible that Matthew 10 also gives evidence of a contemporary mission to the Jews. Chapter 10 then does not only report Jesus' past mission, but also encourages a present mission to Jews encountering fierce difficulties. The relation between the missions towards the Jews and the Gentiles should then

13 The sharp differentiation between the "risen Lord" and "earthly Jesus", however, is debatable. 
be understood as going on simultaneously. In line with such an understanding Strecker (1971:41) interprets the "cities of Israel" (10:23) as referring to the cities of the world where Jews lived, not only cities of Palestine.

How ever one views the relation between the mission towards Israel and the Gentiles, it remains clear that the church mainly consisted of Jews, but also of Gentiles. Openness towards Jews is also evident from Matthew 10 and 25. Thus, while Matthew urges his group to undertake a gentile mission, he continues to appeal to fellow Jews (Saldarini 1994:43). To argue that Matthew had an antiJewish attitude in general is therefore unfounded. The crisis however occurs when Jews would not accept Jesus as Saviour and not adhere to his teaching. Personal commitment to Jesus forms the essence of being part of the church. Matthew opposes people who lack this commitment, whether Jewish of non-Jewish.

The time of exclusive mission to Israel certainly is over. The community's orientation toward mission of Israel has been replaced and broadened toward world-mission. The egnh (Mt 10:5-6) must be distinguished from pant a ta; egnh (Mt 28:19) (Luz 2005:249). Though the ejnh stand in opposition to the "Jews" (Matt 28:15), the expression pant a ta; egnh includes Israel. At least the evangelist does not refer to "all the Jews", but only to "Jews" (Mt 28:15).

\subsection{Authority lies with the church}

The Matthean text exhibits opposition against the authority of Jewish leaders and spokespersons of the synagogues. Religious and political authority and power were inseparable in their societies. It seems that the leaders of the communities were competing with one another to win adherents. Matthew and his community, as Jesus, were in competition with the Jewish community leaders for the hearts of the people (Saldarini 1994:44). The synagogue leaders expelled the Christian community from the synagogues, as has been expressed in the Birkat ha minim. They acted as bearers of the keys to exclude the Jewish Christians from their gatherings. However, Matthew argues that the keys of the kingdom of the heavens have been delegated to the Church.

As the Jewish leadership claimed to lead the synagogue of Israel, Matthew claimed to lead the ekkl hsia according to the 
teachings of Jesus. The formula of Matthew 16:19 14 and 18:18 propose a tremendous degree of authority to Peter and the community. The first pronouncement refers to Peter himself, while the second indicates the corporate responsibility of the community. The authority is exercised by Peter on behalf of the community (Mt 16) as well as by the community corporately (Mt 18).

The keys are not of an earthly organisation, but of the kingdom of heaven. Does Matthew intend to infer unquestionable authority on the decisions of the disciple community? Two considerations suggest caution (France 1989:250). Firstly, Matthew repeatedly emphasises the fallibility of Peter and the disciples - the same disciples who constitute the ekklhsia are those to which the pronouncement is made. Secondly the ekkl hs i a is not of Peter, but that of Jesus. The authority of the church therefore is dependent on Jesus. Jesus has the ultimate authority, but He delegates this in a specific manner to his representatives on earth.

The phrasing of Matthew 16:19 and 18:18 suggests that they originally may have existed independently from their present context. Isaiah $22: 22^{16}$ is generally regarded as the Old Testament background to the metaphor of the keys. In that case Peter and the church's power are not so much that of doorkeepers, but that of stewards. The authority of bounding and loosening should be understood in the light of rabbinic usage of the words that refers to the declaration of what is forbidden or required by the law (cf. Derrett 1983:112-117). These terms therefore refer to a teaching function of stewards who make halakhic pronouncements which are "binding" on the people of God. The authority of earthly pronouncement consists in passing on a decision which has already been made in heaven.

14 Mt 16:19: "I will give you the keys of the kingdom of heaven; whatever you bind on earth will (but rather: have been) be bound in heaven, and whatever you loose on earth will (but rather: have been) be loosed in heaven".

15 Mt 18:18: "I tell you the truth, whatever you bind on earth will be (but rather: have been) bound in heaven, and whatever you loose on earthy will be (rather: have been) loosed in heaven".

16 Is 22:20-22: "On that day I will summon my servant ... I will place on his shoulder the key to the house of David; what heopens no one can shut, and what he shuts no one can open". 
In Matthew 16:18 Jesus promised that He would build his ekklhsia on Simon, who is called the rock. This metaphor of stability also points to the endurance of the Matthean community (Crosby 1988:52). The authority of the community to teach and to structure itself is given in the promise that things bound and loosened on earth will be ratified in heaven (Mt 16:19). Jesus and God is in their midst and their future lies in God's rule (Mt 16:16). The Matthean assembly which is ostensibly small, endangered and separated has its roots in the future of God, its permanence is guaranteed in Jesus, and its authority is validated in heaven. Matthew 18:17 denotes the assembled members of the community. This group tries to correct a member and has disciplinary power recognized by God (Mt 18:18-19). However, the church is not highly institutionalized because God is also authoritatively with two or three gathered together (s unhgmenoi - from the same root as synagogue).

\section{CONCLUSIONS}

The Matthean Gospel should be read as a transparent story on two levels. On the first level Matthew tells how Jesus was rejected and executed in Israel while He pronounced judgement on Israel's leaders and its people and commissioned his disciples to preach to the Gentiles. On the second level he tells the story of the church's commitment to Jesus which resulted in their separation from the synagogue and the forming of a new community of Christian believers. Yet, it should be recognized that no clear and unambiguous picture can be drawn of the community, as this picture depends on interpretation of metaphors and relationships hinted to in the narrative on the first level.

The Matthean community apparently started to form their own structures separately from the synagogues. Because they had been expelled from the synagogues of their opponents, they had to form their own, which they called by another Greek word attributed by Jesus. Matthew's Jesus refers to this new community as the ekkl hs i . Matthew intends to indicate that the Church differentiate itself form the opponents in the sunag wg hy Matthew's avoidance of the term synagogue does not imply that the community was no longer Jewish. The church deviated from the majority. Through its devotion to Jesus as the risen and apocalyptic figure Matthew's community seeks to reform the Jewish society and tries to influence 
the way the society lives and interprets the will of God. Matthew's Jesus depicts his community as the true, faithful remnant of Israel.

Fkklhsia and sunagwghv are both Greek words for an assembly. The meaning and content of ekkl hsia must be derived form the Matthean context. The term does not imply a full blown corporate meaning. However, the ekklhsia is not just a human arrangement to keep social order, but derives its authority and legislation from God through Jesus. Matthew's community poses a counterclaim to the synagogue as divine-human community.

Non-Jews were incorporated into the church which created much tension with Judaistic movements. The community's orienttation toward mission of Israel has been replaced and broadened toward world-mission.

The Matthean text exhibits opposition against the authority of Jewish leaders and spokespersons of the synagogues. Matthew argues that the keys of the kingdom of the heavens have been delegated to the Church and its leaders.

The relation between the synagogue and the church can be described as a sibling conflict. In its self definition the church competed with their related Judaistic groups.

Polemical arguments played an important role in the selfdefinition of the Christian community in the crises of separation and transition. However, Matthew is not anti-Jewish as such, but attacks the hostile Jewish leaders and occasionally the people who followed those leaders into a rejection of Jesus. He also attacks the institutions under their control and the interpretation of the law they propose for the Jewish society. It is crucial to understand that Matthew's largely Jewish community was involved in a local struggle with a specific synagogue community. But what was applicable to that specific situation sadly became a common feature of Christianity through the ages - independent from this specific historical situation. Matthew should not be held responsible for such heartbreaking later developments.

\section{Consulted Literature}

Abel, E 1971. Who wrote Matthew? New Testament Studies 17, 138-152.

Bauckham, R 1998. The Gospels for all Christians: Rethinking the Gospel Audiences. Grand Rapids: Eerdmans. 
Betz, H D 1995. The Sermon on the Mount. A commentary on the Sermon on the Mount, including the Sermon on the Plain. Minneapolis: Fortress Press.

Bornkamm, G 1963. End-Expectation and Church in Matthew, in Bornkamm, G, Barth, G \& Held, H-J (eds). Tradition and Interpretation in Matthew. Philadelphia: Westminster Press.

Brown, J P 1961. The form of “Q” known to Matthew. New Testament Studies 8, 27-42.

Burridge, R A 1994. Four Gospels, one Jesus? Grand Rapids: Eerdmans.

Carter, W 2000. Matthew and the margins. A Socio-Political and Religious reading. Sheffield: Sheffield Academic Press (Journal for the Study of the New Testament Supplement Series, 204).

Clark, K W 1947. The Gentile Bias in Matthew, Journal of Biblical Literature 66, 165-172.

Coser, L A 1998. The functions of social conflict. London: Routley.

Cosby, M H 1988. House of disciples. Church, Economics and Justice in Matthew. New York: Orbis Books.

Derret, J D M 1983. Binding and loosing (Matt. 16:19; 18:18; John 20:23)”. Journal of Biblical Literature 102, 112-117.

Dodd, C H 1979. The founder of Christianity. London: Collins.

Dunn, D G 1980. Christology in the making. London \& Philadelphia: Westminster.

-, 1991. The parting of the ways between Christianity and Judaism and their significance for the character of Christianity. Philadelphia: Trinity Press International.

France, R T 1998. Matthew: Evangelist and teacher. Illinois: Intervarsity Press.

Hare, D R A 1967. The theme of Jewish persecution of Christians in the Gospel according to St. Matthew. Cambridge: University Press.

Horbury, W 1982. The Benediction of the Minim and early Jewish Christian controversy. Journal of Theological Studies 33, 19-61.

Hummel, R 1966. Die Auseinandersetzung zwischen Kirche und Judentum im Matthäusevangelium. München: Kaisar.

Johnson, L T 1986. The writings of the New Testament. Philadelphia: Fortress.

Keener, G S 1999. A commentary on the Gospel of Matthew. Michigan \& Cambridge: Eerdmans.

Klijn, A F J 1968. De wordingsgeschiedenis van het Nieuwe Testament. Utrecht/Antwerpen: Het Spectrum NV.

Luz, U 1990. Matthew 1-7. A commentary. Edinburgh: T \& T Clark.

-, 2005. Studies in Matthew. Grand Rapids \& Cambridge: Eerdmans.

Martin, J P 1975. The Church in Matthew. Interpretation 29(1), 41-56. 
Meier, J P 1976. Law and History in Matthew's Gospel: A redactional study of Mt 5:17-48. Rome: Biblical Institute.

Mohrlang, R 1984. Matthew and Paul: a comparison of ethical perspectives. Cambridge: University Press.

Nepper-Christensen, P 1958. Das Matthäusevangelium: ein juden-christliches Evangelium? Aarhus: Universitetsforlaget.

Przybylski, B 1986. The setting of Matthean Antijudaim, in Richardson, P (ed). Antijudaism in Early Christianity I. Waterloo: Wilfred Laurer University, 181-200.

Overman, J A 1990. Matthew's Gospel and Formative Judaism. The Social World of the Matthean Community. Mineapolis: Fortress Press.

Radford Ruether, R 1974. Faith and fratricide. The Theological roots of AntiSemitism. New York: Seabury.

Repschinski, B 2000. The controversy stories in the Gospel of Matthew: Their redaction, form and relevance for the relationship between the Matthean community and formative Judaism. Göttingen: Vandenhoeck \& Ruprecht.

Saldarini, A J 1991. The Gospel of Matthew and Jewish-Christian conflict, in: Balch, DL (ed). Social History of the Matthean community. Crossdisciplinary approaches. Minneapolis: Fortress Press, 38-61.

-, 1994. Matthew's Christian-Jewish Community. Chicago \& London: University of Chicago.

Stanton, G N 1977. 5 Ezra and Matthian Christianity. Journal of Theological Studies 28, 67-88.

- , 1992. Matthew's Christology and the parting of the ways, in: Dunn, J D G (ed.). The parting of the ways A.D. 70 to 135. The second Durham-Tübingen research symposium on earliest Christianity and Judaism (Durham, September 1989). WUNT 66. Tübingen: Mohr (Siebeck), 99-116.

-, 1993. A gospel for a new people: Studies in Matthew. Edinburgh: T \& T Clark.

Strecker, G 1971. Der Weg der Gerechtigkeit. Untersuchung zur Theologie des Matthäus. Göttingen: Vandenhoeck \& Ruprecht.

Streeter, B H 1924. The four gospels: A study of origins. London: Macmillan.

Tagawa, K 1969/70. People and community in the Gospel of Matthew. New Testament Studies 16, 49-62.

Telford, W R 1980. The barren temple and the withered tree. Sheffield: JSOT Press.

Thompson, W G 1970. Matthew's advice to a divided community: Mt 17, 2218,35. Rome: Biblical Institute Press.

Van Tilborg, S 1972. The Jewish leaders in Matthew. Leiden: Brill.

Versteeg, J P 1980. Evangelie in viervoud: Een karakteristiek van de vier evangeliën. Kampen: Kok. 
Wilson, A I 2004. When will these things happen? A study of Jesus as Judges in Matthew 21-25. Cumbria: Paternoster.

Yueh-Han Yieh, J 2004. One Teacher. Jesus' teaching role in Matthew's Gospel report. Berlin \& New York: Walter de Gruyter (Beihefte zur Zeitschrift für die neutestamentliche Wissenschaft, Band 124). 